\title{
Fluorine Concentrations in Greenhouse Soils Sampled from Farms in Southern Kyushu, Japan
}

\author{
Isao AKAGI, Yoshitaka SATOH and Naoya CHISHAKI \\ Department of Biochemical Science and Technology, Faculty of Agriculture, Kagoshima University \\ (1-21-24 Korimoto, Kagoshima, Kagoshima 890-0065, Japan)
}

[Received September 3, 2014; Accepted December 24, 2014]

\begin{abstract}
Summary
Phosphate fertilizer is thought to be the major source of $\mathrm{F}$ input in agricultural soils. We consider that $\mathrm{F}$ accumulation in Japanese agricultural soil is caused by excessive application of phosphate fertilizer, because Japan is one of the major chemical fertilizer consumer nations in the world. In this study, we analyzed the F concentration in greenhouse soils sampled from farms in southern Kyushu, Japan, and investigated the possibility of the F accumulation in the soils by comparing the concentrations in the greenhouse soils with those in neighboring non-cultivated soils. The total $\mathrm{F}$ concentration in non-cultivated soils and greenhouse soils ranged from 53 to $248 \mathrm{mg} / \mathrm{kg}$ and from 163 to $471 \mathrm{mg} / \mathrm{kg}$, respectively. Almost all greenhouse soils had a higher total $\mathrm{F}$ concentration than the neighboring non-cultivated soils, which indicates that total $\mathrm{F}$ concentrations were generally higher in almost all greenhouse soils. The water-soluble $\mathrm{F}$ concentrations in non-cultivated soils and greenhouse soils ranged from 0.15 to $4.89 \mathrm{mg} / \mathrm{kg}$ and from 1.75 to $20.3 \mathrm{mg} / \mathrm{kg}$, respectively. As well as total F concentration, almost all greenhouse soils had a higher water-soluble $\mathrm{F}$ concentration than the neighboring non-cultivated soils. A positive correlation was observed between the total $\mathrm{F}$ and the total $\mathrm{P}$ concentrations in greenhouse soils, which indicates that the $\mathrm{F}$ in the greenhouse soils is derived from phosphate fertilizers. The above results indicate that soil $\mathrm{F}$ accumulation is due to excessive application of phosphate fertilizers that are widely used on greenhouse soils throughout Japan, and water-soluble F concentrations are correspondingly elevated in these soils.
\end{abstract}

Key words: Soil fluorine concentration, Greenhouse soil, Application of phosphate fertilizer

\section{INTRODUCTION}

Phosphate fertilizer is an indispensable agricultural material for stable crop production. Phosphate fertilizers are frequently used to improve soil fertility, especially in Japan where Andosols, which have a high phosphorus (P) fixing capacity, are distributed widely. Because phosphate fertilizers contain around $10-20 \mathrm{~g} / \mathrm{kg}$ fluorine (F) depending on the origin of the phosphate rock used ${ }^{1)}$, they are thought to be the major source of $\mathrm{F}$ in agricultural soils ${ }^{2,3}$. Recently, in New Zealand and Australia, it has become clear that $\mathrm{F}$ accumulation in pasture soils is caused by the continuing phosphate fertilizer application. Loganathan et $\mathrm{al}^{4}{ }^{4)}$ reported that the F concentrations in New Zealand pasture soils that had received phosphate fertilizer were 1.3-2.2 times higher than in soils that had not been fertilized.

Japan is one of the major chemical fertilizer consumer nations in the world. In 2005, chemical fertilizers containing phosphate were applied at a rate of $99 \mathrm{~kg} \mathrm{P} / \mathrm{ha} / \mathrm{year}$ in $\mathrm{Japan}^{5}$. The continuing excessive use of phosphate fertilizer has recently been reported to have caused accumulation of $\mathrm{P}$ in agricultural soils in Japan ${ }^{6}$. According to monitoring survey data of soil properties from 1979 to 1997 , from $54 \%$ to $78 \%$ of greenhouse soils in Japan showed extremely high concentrations of available $\mathrm{P}(0.001 \mathrm{~mol} / \mathrm{L}$ sulfuric acid-extractable phosphate) exceeding the recommended level ${ }^{7}$. Given the above facts, we consider that $\mathrm{F}$ accumulation in agriculture soils in Japan is caused by excessive application of phosphate fertilizers. However, a few studies have investigated $\mathrm{F}$ concentrations in Japanese agricultural soils ${ }^{8)}$, but no information is available on the effects of the application of phosphate fertilizer on $\mathrm{F}$ accumulation in agricultural soils.

In this study, we analyzed the F concentrations in greenhouse soils sampled from farms in southern Kyushu, Japan, and investigated the possibility of the $\mathrm{F}$ accumulation in the soil by comparing the $\mathrm{F}$ concentrations of the greenhouse soils with those of the neighboring non-cultivated soils.

\section{MATERIALS AND METHODS}

\section{Soil samples}

Thirty-four soil samples were collected from 11 areas in southern Kyushu (Fig. 1). Of these 34 samples, 23 were collected from farm greenhouses and 11 were collected from the non-cultivated fields adjacent to the greenhouses. Soils were taken using a stainless steel trowel from the $15 \mathrm{~cm}$ surface layer soil at each sampling site in midMay to early June after the cultivation period. Soil samples were airdried and passed through $2 \mathrm{~mm}$ mesh sieves before analysis. These soil samples were classified into three groups: Gray Lowland soils, Andosols, and Sand-dune Regosols according to "Classification of Cultivated Soils in Japan, Third Approximation" ${ }^{9)}$. The sample numbers, sampling areas, soil groups and land use are listed in Table 1. 


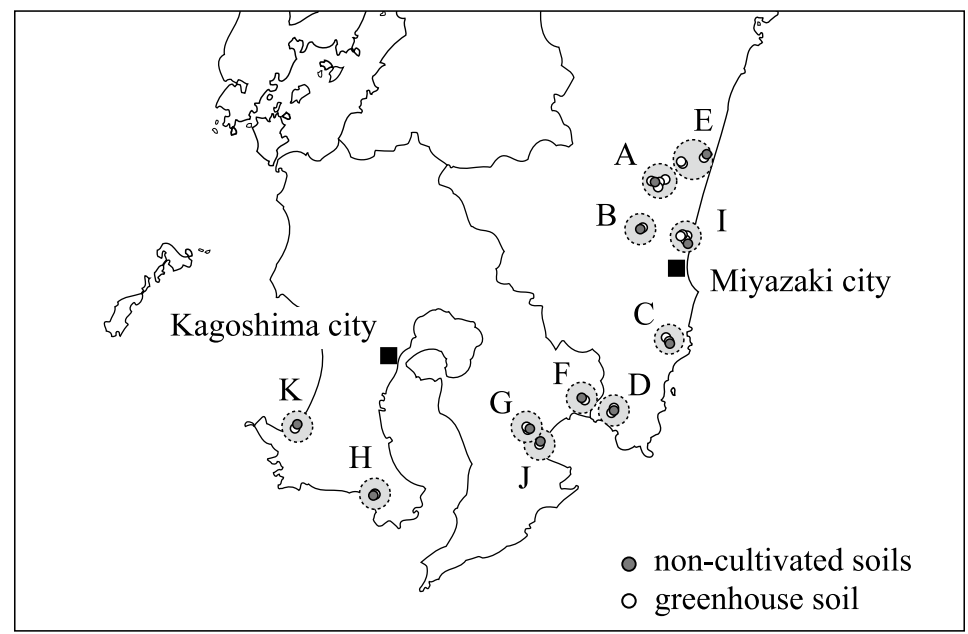

Fig. 1 Map showing the locations of sampling sites in southern Kyushu, Japan

Table 1 Brief description of the sampling sites

\begin{tabular}{|c|c|c|c|}
\hline Location & Soil group & $\begin{array}{c}\text { Sample } \\
\text { No. } \\
\end{array}$ & Land use \\
\hline $\begin{array}{l}\text { A: Saito City, } \\
\text { Miyazaki Pref. }\end{array}$ & Gray Lowland soils & $\begin{array}{l}\mathrm{A}-0 \\
\mathrm{~A}-1 \\
\mathrm{~A}-2 \\
\mathrm{~A}-3 \\
\mathrm{~A}-4\end{array}$ & $\begin{array}{l}\text { Non-cultivated field } \\
\text { Greenhouse field } \\
\text { Greenhouse field } \\
\text { Greenhouse field } \\
\text { Greenhouse field }\end{array}$ \\
\hline $\begin{array}{l}\text { B: Higashimorokata District, } \\
\text { Miyazaki Pref. }\end{array}$ & Gray Lowland soils & $\begin{array}{l}\mathrm{B}-0 \\
\mathrm{~B}-1\end{array}$ & $\begin{array}{l}\text { Non-cultivated field } \\
\text { Greenhouse field }\end{array}$ \\
\hline $\begin{array}{l}\text { C: Nichinan City, } \\
\text { Miyazaki Pref. }\end{array}$ & Gray Lowland soils & $\begin{array}{l}\mathrm{C}-0 \\
\mathrm{C}-1 \\
\mathrm{C}-2 \\
\mathrm{C}-3\end{array}$ & $\begin{array}{l}\text { Non-cultivated field } \\
\text { Greenhouse field } \\
\text { Greenhouse field } \\
\text { Greenhouse field }\end{array}$ \\
\hline $\begin{array}{l}\text { D: Kushima City, } \\
\text { Miyazaki Pref. }\end{array}$ & Gray Lowland soils & $\begin{array}{l}D-0 \\
D-1 \\
D-2\end{array}$ & $\begin{array}{l}\text { Non-cultivated field } \\
\text { Greenhouse field } \\
\text { Greenhouse field }\end{array}$ \\
\hline $\begin{array}{l}\text { E: Koyu District, } \\
\text { Miyazaki Pref. }\end{array}$ & Andosols & $\begin{array}{l}\text { E-0 } \\
\text { E-1 } \\
\text { E-2 } \\
\text { E-3 }\end{array}$ & $\begin{array}{l}\text { Non-cultivated field } \\
\text { Greenhouse field } \\
\text { Greenhouse field } \\
\text { Greenhouse field }\end{array}$ \\
\hline $\begin{array}{l}\text { F: Shibushi City, } \\
\text { Kagoshima Pref. }\end{array}$ & Andosols & $\begin{array}{l}F-0 \\
F-1\end{array}$ & $\begin{array}{l}\text { Non-cultivated field } \\
\text { Greenhouse field }\end{array}$ \\
\hline $\begin{array}{c}\text { G: Kimotsuki District, } \\
\text { Kagoshima Pref. }\end{array}$ & Andosols & $\begin{array}{l}\mathrm{G}-0 \\
\mathrm{G}-1 \\
\mathrm{G}-2\end{array}$ & $\begin{array}{l}\text { Non-cultivated field } \\
\text { Greenhouse field } \\
\text { Greenhouse field }\end{array}$ \\
\hline $\begin{array}{l}\text { H: Minamikyushu City, } \\
\text { Kagoshima Pref. }\end{array}$ & Andosols & $\begin{array}{l}\mathrm{H}-0 \\
\mathrm{H}-1\end{array}$ & $\begin{array}{l}\text { Non-cultivated field } \\
\text { Greenhouse field }\end{array}$ \\
\hline $\begin{array}{l}\text { I: } \quad \text { Miyazaki City, } \\
\text { Miyazaki Pref. }\end{array}$ & Sand-dune Regosols & $\begin{array}{l}\mathrm{I}-0 \\
\mathrm{I}-1 \\
\mathrm{I}-2 \\
\mathrm{I}-3 \\
\mathrm{I}-4\end{array}$ & $\begin{array}{l}\text { Non-cultivated field } \\
\text { Greenhouse field } \\
\text { Greenhouse field } \\
\text { Greenhouse field } \\
\text { Greenhouse field }\end{array}$ \\
\hline $\begin{array}{c}\text { J: Kimotsuki District, } \\
\text { Kagoshima Pref. }\end{array}$ & Sand-dune Regosols & $\begin{array}{l}\mathrm{J}-0 \\
\mathrm{~J}-1\end{array}$ & $\begin{array}{l}\text { Non-cultivated field } \\
\text { Greenhouse field }\end{array}$ \\
\hline $\begin{array}{c}\text { K: Minamisatsuma City, } \\
\text { Kagoshima Pref. }\end{array}$ & Sand-dune Regosols & $\begin{array}{l}\mathrm{K}-0 \\
\mathrm{~K}-1\end{array}$ & $\begin{array}{l}\text { Non-cultivated field } \\
\text { Greenhouse field }\end{array}$ \\
\hline
\end{tabular}




\section{Analytical methods}

Soil $\mathrm{pH}$ was measured with a glass electrode $\mathrm{pH}$ meter (F-51; Horiba) in a water suspension with the ratio of soil to distilled water adjusted to 1:2.5 weight/volume ${ }^{10)}$. The concentration of total $\mathrm{C}$ was measured using a dry combustion method (Macro corder JM1000CN; $\mathrm{J}$-Science $\mathrm{Lab})^{10}{ }^{10}$. Amorphous $\mathrm{Al}$ and Fe were extracted by shaking $0.5 \mathrm{~g}$ of soil with $50 \mathrm{~mL}$ of oxalate solution $(0.2 \mathrm{~mol} / \mathrm{L}$ oxalic acid and ammonium oxalate solution, $\mathrm{pH}$ 3.0) for 4 hours $^{10,11}$. $\mathrm{Al}$ and $\mathrm{Fe}$ in this extract were determined by inductively coupled plasma-atomic emission spectroscopy (ICP-AES, SPS1700VR; Seiko Instruments). The concentration of total $\mathrm{P}$ was determined by the vanadomolybdate spectrophotometric method after digestion with a mixture of nitric and perchloric acids on a hot plate ${ }^{10)}$.

Total $\mathrm{F}$ was separated by steam distillation in the presence of sulfuric acid $\left(\mathrm{H}_{2} \mathrm{SO}_{4}\right){ }^{12}$. A 1-g soil sample was distilled at $145 \pm 5{ }^{\circ} \mathrm{C}$ with $80 \mathrm{~mL}$ of $9 \mathrm{~mol} / \mathrm{L} \mathrm{H}_{2} \mathrm{SO}_{4}, 1 \mathrm{~mL}$ of phosphoric acid and $1 \mathrm{~g}$ of silicon dioxide. Approximately $200 \mathrm{~mL}$ of the distillate was collected at a rate of about $3-5 \mathrm{~mL}$ per minute. $\mathrm{F}$ in the distillate was determined by a spectrophotometric method with lanthanum-alizarin complexone $(\mathrm{La}-\mathrm{AC})^{13)}$. The La-AC reagent was prepared by dissolving Dotite Alfusone (Dojin Chemical). To the distillate solution was added $2 \mathrm{~mL}$ of $1.0 \mathrm{~mol} / \mathrm{L}$ acetate buffer (pH 5.0), $2 \mathrm{~mL}$ of acetyl acetone, $5 \mathrm{~mL}$ of 10 $\mathrm{g} / \mathrm{L} \mathrm{La}-\mathrm{AC}$ reagent and $10 \mathrm{~mL}$ of acetone, and the solution was made up to $50 \mathrm{~mL}$ with distilled water ${ }^{14,15)}$. The absorption of the prepared solution was measured at $620 \mathrm{~nm}$ after 1 hour.

Water-soluble $\mathrm{F}$ was extracted by shaking $1 \mathrm{~g}$ soil with $50 \mathrm{~mL}$ ultrapure water for 2 hours $^{8)}$. After shaking, the suspension was filtered through no. 5C Advantec filter paper. $\mathrm{F}$ in the extract was determined by a spectrophotometric method with $\mathrm{La}-\mathrm{AC}$ as described above.

\section{RESULTS AND DISCUSSION}

\section{Total F concentration}

The total $\mathrm{F}$ concentration in non-cultivated soils and greenhouse soils ranged from 53 to $248 \mathrm{mg} / \mathrm{kg}$ (median $169 \mathrm{mg} / \mathrm{kg}$ ) and from 163 to $471 \mathrm{mg} / \mathrm{kg}$ (median $258 \mathrm{mg} / \mathrm{kg}$ ), respectively (Table 2). These ranges lie within the ranges reported for world soils $\left(8-990 \mathrm{mg} / \mathrm{kg}^{3}\right.$, $\left.20-1,000 \mathrm{mg} / \mathrm{kg}^{16)}\right)$. There were differences in the total $\mathrm{F}$ concentrations in the non-cultivated soils among the three soil groups $(p=0.049$, Kruskal-Wallis test): the concentration ranges in the Gray Lowland Soils, Andosols, and Sand-dune Regosols were 168-247 mg/kg (median $207 \mathrm{mg} / \mathrm{kg}$ ), 122-248 mg/kg (median $191 \mathrm{mg} / \mathrm{kg}$ ), and 53-72 $\mathrm{mg} / \mathrm{kg}$ (median $72 \mathrm{mg} / \mathrm{kg}$ ), respectively. These differences may reflect differences in the parent materials and soil-forming processes.

All greenhouse soils except three (samples A-2, A-4, and D-1) had a higher total $\mathrm{F}$ concentration than the neighboring non-cultivated soils; for example, the total $\mathrm{F}$ concentrations in the greenhouse soils I-1 (203 mg/kg), I-2 (321 mg/kg), I-3 (246 mg/kg), and I-4 (282 $\mathrm{mg} / \mathrm{kg}$ ) were $2.8,4.5,3.4$ and 3.9 times higher than those in the neighboring non-cultivated soil I-0 $(72 \mathrm{mg} / \mathrm{kg})$. This result shows that the total $\mathrm{F}$ concentration was elevated in almost all greenhouse soils. The total $\mathrm{F}$ accumulated in the greenhouse soils was estimated at 17-249 $\mathrm{mg}$ per $\mathrm{kg}$ of oven-dry soil by subtracting the total F concentration in the greenhouse soils from the total $\mathrm{F}$ concentration in the neighboring non-cultivated soils.

The $\mathrm{F}$ accumulated in the greenhouse soils is considered to be derived from phosphate fertilizer, because phosphate fertilizer contains around $10-20 \mathrm{~g} \mathrm{~F} / \mathrm{kg}^{1)}$ and is frequently used for greenhouse culture in Japan. The chemical properties of the greenhouse soils and the non-cultivated soils are listed in Table 2. Total P concentrations in the greenhouse soils $(2.59-10.3 \mathrm{mg} / \mathrm{kg})$ were significantly higher than in the non-cultivated soils $(0.07-1.39 \mathrm{~g} / \mathrm{kg})$. All greenhouse soils had a higher total $\mathrm{P}$ concentration than the neighboring non-cultivated soils; for example, the total $\mathrm{P}$ concentrations in the greenhouse soils I-1 (5.45 g/ kg), I-2 (10.3 g/kg), I-3 (7.18 g/ kg), and I-4 (4.61 g/ $\mathrm{kg})$ were $45,86,60$ and 38 times higher than in the neighboring noncultivated soil I-0 $(0.12 \mathrm{~g} / \mathrm{kg})$. Phosphate fertilizer has been used almost exclusively as a source of $\mathrm{P}$ nutrition, although animal manure compost and other material containing some $\mathrm{P}$ have often been added at the sampling sites. Thus, the increase in total $\mathrm{P}$ concentration appears to be a result of the application of phosphate fertilizer.

Correlations between total $\mathrm{F}$ concentration in the soils and some chemical properties of the soils are shown in Table 3. Total $\mathrm{F}$ concentration showed a significant positive correlation with total $\mathrm{P}$ concentration (Spearman's rank correlation coefficient, $r_{\mathrm{s}}=0.683, p<0.001$, Fig. 2). A positive correlation was also observed for each soil group separately (Gray Lowland soils, $r_{\mathrm{s}}=0.634$; Andosols, $r_{\mathrm{s}}=0.527$; Sanddune Regosols, $r_{\mathrm{s}}=0.849$ ). Thus the elevation in $\mathrm{F}$ concentration was associated with elevation in $\mathrm{P}$ concentration due to excessive application of phosphate fertilizer. A similar relationship was observed in New Zealand pasture soils treated with phosphate fertilizer ${ }^{4}$. Furthermore, total $\mathrm{F}$ concentration also showed a positive correlation with total $\mathrm{C}$ concentration $\left(r_{\mathrm{s}}=0.472, p=0.005\right)$, amorphous Fe concentration $\left(r_{\mathrm{s}}=0.491, p=0.003\right)$, and amorphous Al concentration $\left(r_{\mathrm{s}}\right.$ $=0.390, p=0.023)$. The correlations can be considered to be related to the strong $\mathrm{F}$ adsorption capacity of amorphous $\mathrm{Al}$ and $\mathrm{Fe}$ oxide/ hydroxide and Al-humus complex ${ }^{17,18)}$. The correlation between total $\mathrm{F}$ and amorphous $\mathrm{Al}$ concentration in our soils was quite weak in comparison with that in New Zealand pasture soils $(r=0.498)$ reported Loganathan et $\mathrm{al}^{22)}$. This shows that a soil component other than $\mathrm{Al}$, for example Ca capable of forming apatite, might play an important role in the retention of $\mathrm{F}$ in the soils studied here.

The above results indicate that soil $\mathrm{F}$ accumulation is due to excessive application of phosphate fertilizer that is widely used on greenhouse culture. This is the first finding in Japan, although it has often been pointed out that application of fertilizer may have caused $\mathrm{F}$ accumulation in agricultural soils. Robinson and Edgington ${ }^{19)}$ reported that the amount of $\mathrm{F}$ accumulated in soils that had received fertilizer for 40 years in New Jersey, USA, were up to $144 \mathrm{mg} / \mathrm{kg}$. Loganathan et al. ${ }^{6}$ reported that the amount of $\mathrm{F}$ accumulated in New Zealand pasture soils that had received fertilizer for 20 years was 143 $\mathrm{mg} / \mathrm{kg}$. In this study some greenhouse soils had accumulated up to $200 \mathrm{mg} / \mathrm{kg}$, which indicates that the $\mathrm{F}$ accumulation has progressed more in Japanese greenhouse soils than in the soils investigated in the above two studies. The F content of phosphate fertilizer is known to vary depending on the fertilizer type and the origin of the phosphate rock used as raw material ${ }^{1}$. Thus, the degree of $\mathrm{F}$ accumulation in the soil may be affected by not only the amount but also the quality of the added fertilizer. It is impossible to evaluate this possibility at present because the fertilizer history of the sampling site is not accurately known. 
Table 2 Fluorine concentration (total $\mathrm{F}$ and water-soluble $\mathrm{F}$ ) and soil chemical properties in noncultivated soils and greenhouse soils

\begin{tabular}{|c|c|c|c|c|c|c|c|c|c|c|c|}
\hline \multirow[b]{2}{*}{$\begin{array}{c}\text { Sample } \\
\text { No. }\end{array}$} & \multirow[b]{2}{*}{$\begin{array}{c}\text { Soil } \\
\text { group }^{1)}\end{array}$} & \multirow[b]{2}{*}{$\begin{array}{l}\text { Land } \\
\text { use }^{2)}\end{array}$} & \multicolumn{4}{|c|}{ F concentration } & \multirow[b]{2}{*}{$\mathrm{pH}$} & \multirow[b]{2}{*}{$\begin{array}{l}\text { Total C } \\
(\mathrm{g} / \mathrm{kg}) \\
\end{array}$} & \multirow[b]{2}{*}{$\begin{array}{c}\text { Total } \\
\mathrm{P} \\
(\mathrm{g} / \mathrm{kg}) \\
\end{array}$} & \multicolumn{2}{|c|}{ Amorphous } \\
\hline & & & $\begin{array}{l}\text { Total F } \\
(\mathrm{mg} / \mathrm{kg})\end{array}$ & $\begin{array}{c}\Delta \text { total F }^{3)} \\
(\mathrm{mg} / \mathrm{kg})\end{array}$ & $\begin{array}{c}\text { Water- } \\
\text { soluble F } \\
(\mathrm{mg} / \mathrm{kg})\end{array}$ & $\begin{array}{l}\Delta \text { water- } \\
\left.\text { solble F }{ }^{4}\right) \\
(\mathrm{mg} / \mathrm{kg})\end{array}$ & & & & $\begin{array}{c}\mathrm{Al} \\
(\mathrm{g} / \mathrm{kg}) \\
\end{array}$ & $\begin{array}{c}\mathrm{Fe} \\
(\mathrm{g} / \mathrm{kg})\end{array}$ \\
\hline $\mathrm{A}-0$ & G & $\mathrm{NC}$ & 247 & - & 4.89 & - & 4.7 & 18.4 & 1.39 & 1.88 & 6.42 \\
\hline A-1 & G & $\mathrm{G}$ & 275 & 28 & 3.78 & -1.11 & 5.4 & 16.8 & 3.60 & 2.88 & 5.19 \\
\hline $\mathrm{A}-2$ & $\mathrm{G}$ & $\mathrm{G}$ & 239 & -8 & 3.07 & -1.82 & 6.4 & 33.6 & 4.57 & 3.71 & 4.86 \\
\hline A-3 & G & G & 292 & 45 & 4.02 & -0.87 & 5.7 & 26.6 & 4.59 & 2.14 & 4.50 \\
\hline$A-4$ & G & $\mathrm{G}$ & 243 & -4 & 2.06 & -2.83 & 5.9 & 26.1 & 3.59 & 2.26 & 3.28 \\
\hline $\mathrm{B}-0$ & G & $\mathrm{NC}$ & 213 & - & 2.14 & - & 5.3 & 21.3 & 0.43 & 2.24 & 5.98 \\
\hline B-1 & $\mathrm{G}$ & $\mathrm{G}$ & 435 & 222 & 20.3 & 18.2 & 6.8 & 44.0 & 6.65 & 36.4 & 12.4 \\
\hline $\mathrm{C}-0$ & $\mathrm{G}$ & $\mathrm{NC}$ & 201 & - & 1.57 & - & 5.3 & 45.5 & 0.43 & 12.5 & 6.43 \\
\hline $\mathrm{C}-1$ & $\mathrm{G}$ & $\mathrm{G}$ & 258 & 58 & 4.97 & 3.40 & 5.8 & 34.7 & 5.81 & 10.3 & 7.08 \\
\hline $\mathrm{C}-2$ & $\mathrm{G}$ & $\mathrm{G}$ & 230 & 29 & 4.59 & 3.02 & 5.6 & 16.2 & 4.75 & 2.17 & 4.54 \\
\hline $\mathrm{C}-3$ & $\mathrm{G}$ & $\mathrm{G}$ & 273 & 72 & 3.74 & 2.17 & 6.1 & 33.8 & 7.49 & 7.00 & 6.23 \\
\hline $\mathrm{D}-0$ & $\mathrm{G}$ & $\mathrm{NC}$ & 168 & - & 2.94 & - & 4.8 & 21.6 & 1.08 & 4.47 & 4.48 \\
\hline D-1 & $\mathrm{G}$ & $\mathrm{G}$ & 163 & -5 & 5.89 & 2.95 & 6.2 & 21.3 & 2.59 & 10.1 & 3.74 \\
\hline D-2 & $\mathrm{G}$ & G & 185 & 17 & 6.41 & 3.47 & 6.2 & 20.1 & 3.74 & 4.94 & 3.21 \\
\hline $\mathrm{E}-0$ & A & $\mathrm{NC}$ & 248 & - & 0.15 & - & 4.8 & 75.8 & 0.71 & 39.0 & 16.6 \\
\hline E-1 & A & $\mathrm{G}$ & 471 & 223 & 2.00 & 1.85 & 5.3 & 93.1 & 5.42 & 55.9 & 17.6 \\
\hline E-2 & A & $\mathrm{G}$ & 391 & 143 & 1.75 & 1.59 & 5.4 & 87.6 & 4.48 & 53.1 & 18.5 \\
\hline E-3 & A & G & 353 & 105 & 1.98 & 1.83 & 5.1 & 119. & 5.04 & 44.1 & 13.9 \\
\hline $\mathrm{F}-0$ & A & $\mathrm{NC}$ & 169 & - & 0.39 & - & 5.3 & 52.6 & 0.40 & 69.9 & 15.7 \\
\hline $\mathrm{F}-1$ & A & $\mathrm{G}$ & 251 & 82 & 14.6 & 14.2 & 6.6 & 43.7 & 5.17 & 38.4 & 10.4 \\
\hline $\mathrm{G}-0$ & A & $\mathrm{NC}$ & 214 & - & 0.44 & - & 5.4 & 49.0 & 0.53 & 38.4 & 10.4 \\
\hline $\mathrm{G}-1$ & A & $\mathrm{G}$ & 265 & 51 & 3.79 & 3.35 & 5.1 & 54.2 & 9.79 & 20.9 & 9.24 \\
\hline $\mathrm{G}-2$ & A & G & 288 & 74 & 7.98 & 7.54 & 5.5 & 82.6 & 9.71 & 33.2 & 13.0 \\
\hline $\mathrm{H}-0$ & A & $\mathrm{NC}$ & 122 & - & 1.31 & - & 5.5 & 47.5 & 0.77 & 35.6 & 14.4 \\
\hline $\mathrm{H}-1$ & A & $\mathrm{G}$ & 217 & 95 & 5.54 & 4.22 & 5.5 & 50.5 & 6.51 & 27.6 & 14.8 \\
\hline $\mathrm{I}-0$ & S & $\mathrm{NC}$ & 72 & - & 1.14 & - & 5.2 & 4.1 & 0.12 & 0.85 & 2.51 \\
\hline $\mathrm{I}-1$ & $\mathrm{~S}$ & $\mathrm{G}$ & 203 & 131 & 3.06 & 1.93 & 6.5 & 18.4 & 5.45 & 5.01 & 2.05 \\
\hline $\mathrm{I}-2$ & $\mathrm{~S}$ & G & 321 & 249 & 1.79 & 0.65 & 4.9 & 32.7 & 10.3 & 8.20 & 5.79 \\
\hline $\mathrm{I}-3$ & $\mathrm{~S}$ & $\mathrm{G}$ & 246 & 174 & 3.05 & 1.92 & 6.0 & 20.3 & 7.18 & 6.97 & 3.59 \\
\hline I-4 & $\mathrm{S}$ & $\mathrm{G}$ & 282 & 210 & 8.59 & 7.45 & 5.7 & 18.4 & 4.61 & 5.71 & 2.61 \\
\hline $\mathrm{J}-0$ & S & $\mathrm{NC}$ & 72 & - & 1.15 & - & 5.5 & 2.9 & 0.07 & 1.42 & 1.58 \\
\hline $\mathrm{J}-1$ & $\mathrm{~S}$ & $\mathrm{G}$ & 170 & 98 & 3.09 & 1.95 & 4.7 & 24.7 & 4.15 & 9.59 & 4.54 \\
\hline $\mathrm{K}-0$ & $\mathrm{~S}$ & $\mathrm{NC}$ & 53 & - & 1.22 & - & 5.3 & 9.5 & 0.14 & 0.74 & 0.72 \\
\hline $\mathrm{K}-1$ & $\mathrm{~S}$ & $\mathrm{G}$ & 210 & 139 & 8.56 & 7.34 & 6.1 & 35.8 & 4.61 & 3.15 & 2.22 \\
\hline
\end{tabular}

1) Soil group: G, Gray Lowland soils; A, Andosols; S, Sand-dune Regosols.

2) Land use: NC, non-cultivated field; G, greenhouse field.

3) $\Delta$ total F: Amount of accumulated total $\mathrm{F}=$ total $\mathrm{F}$ concentration in the greenhouse soil - total $\mathrm{F}$ concentration in the neighboring non-cultivated soils

4) $\Delta$ water-soluble F: Amount of accumulated water-soluble F = water-soluble F concentration in the greenhouse soil - watersoluble $\mathrm{F}$ concentration in the neighboring non-cultivated soils

Table 3 Spearman's rank correlation coefficient $\left(r_{\mathrm{s}}\right)$ between $\mathrm{F}$ concentration (total $\mathrm{F}$ and watersoluble F) and soil chemical properties

\begin{tabular}{ccccccc}
\hline & Total F & $\mathrm{pH}$ & Total C & Total P & $\begin{array}{c}\text { Amorphous } \\
\text { Al }\end{array}$ & $\begin{array}{c}\text { Amorphous } \\
\text { Fe }\end{array}$ \\
\hline \hline Total F & - & $0.065(0.715)$ & $0.472(0.005)$ & $0.683(<0.001)$ & $0.390(0.023)$ & $0.491(0.003)$ \\
Water-soluble F & $0.302(0.083)$ & $0.558(0.001)$ & $-0.094(0.596)$ & $0.585(<0.001)$ & $-0.087(0.623)$ & $-0.131(0.459)$ \\
\hline
\end{tabular}

Numbers in parentheses indicate $p$-value 


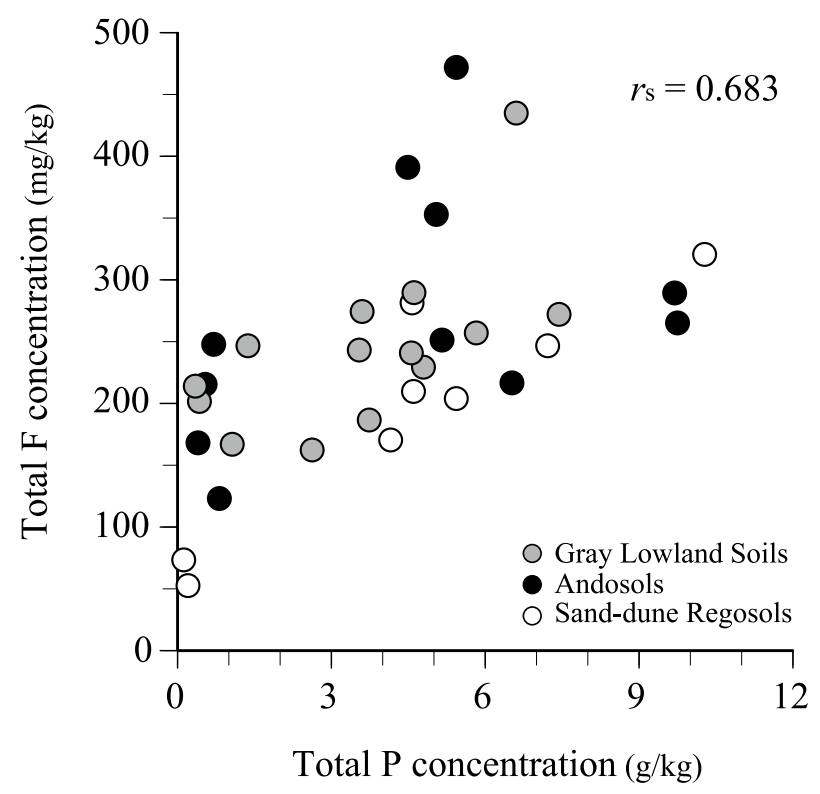

Fig. 2 Relationship between total $\mathrm{P}$ concentration and total $\mathrm{F}$ concentration in non-cultivated soils and greenhouse soils

\section{Water-soluble $F$ concentration}

The water-soluble $\mathrm{F}$ concentrations in non-cultivated and greenhouse soils ranged from 0.15 to $4.89 \mathrm{mg} / \mathrm{kg}$ (median $1.22 \mathrm{mg} / \mathrm{kg}$ ) and from 1.75 to $20.3 \mathrm{mg} / \mathrm{kg}$ (median $3.79 \mathrm{mg} / \mathrm{kg}$ ), respectively (Table 2). Compared with total $F$ concentration, water-soluble $F$ concentrations were very low; the proportion of total $\mathrm{F}$ present as water-soluble $\mathrm{F}$ was $0.1-5.8 \%$. The result suggests that most $\mathrm{F}$ in soil is present in insoluble form, as already reported ${ }^{3,17,20)}$. As well as the total $\mathrm{F}$ concentration, there were differences in water-soluble $\mathrm{F}$ concentrations in the non-cultivated soils among the three soil groups $(p=0.024$, Kruskal-Wallis test): the concentration ranges in Gray Lowland Soils, Andosols and Sand-dune Regosols were 1.57-4.89 mg/kg (median $2.59 \mathrm{mg} / \mathrm{kg}$ ), $0.15-1.31 \mathrm{mg} / \mathrm{kg}$ (median $0.42 \mathrm{mg} / \mathrm{kg}$ ) and $1.14-1.22$ $\mathrm{mg} / \mathrm{kg}$ (median $1.15 \mathrm{mg} / \mathrm{kg}$ ), respectively.

All greenhouse soils except four (samples A-1, A-2, A-3, and A-4) had higher water-soluble $\mathrm{F}$ concentrations than the neighboring noncultivated soils; for example, the water-soluble $\mathrm{F}$ concentrations in the greenhouse soils E-1 $(2.00 \mathrm{mg} / \mathrm{kg}), \mathrm{E}-2(1.75 \mathrm{mg} / \mathrm{kg})$ and E-3 $(1.98$ $\mathrm{mg} / \mathrm{kg}$ ) were 13, 12 and 13 times higher, respectively, than in the neighboring non-cultivated soil E- $0(0.15 \mathrm{mg} / \mathrm{kg})$. This result shows that not only total $\mathrm{F}$ concentration but also water-soluble $\mathrm{F}$ concentration was elevated in greenhouse soils. However, there was no significant correlation either between the total $\mathrm{F}$ concentration and the water-soluble $\mathrm{F}$ concentration $\left(r_{\mathrm{s}}=0.302, p=0.083\right)$ or between the amount of accumulated total $\mathrm{F}$ and the amount of accumulated watersoluble $\mathrm{F}\left(r_{\mathrm{s}}=0.219, p=0.315\right)$.

It is known that the water-soluble $\mathrm{F}$ concentration in soil reflects a number of factors affecting the solubility of $\mathrm{F}$ in soil ${ }^{18)}$. Correlations between water-soluble $\mathrm{F}$ concentration in soil and some chemical properties of the soil are summarized in Table 3. Water-soluble $\mathrm{F}$ concentration showed a significant positive correlation with total $\mathrm{P}$ concentration ( $r_{\mathrm{s}}=0.585, p<0.001$, Fig. 3 ). This correlation indicates that there is a link between water-soluble $\mathrm{F}$ concentration in the soil

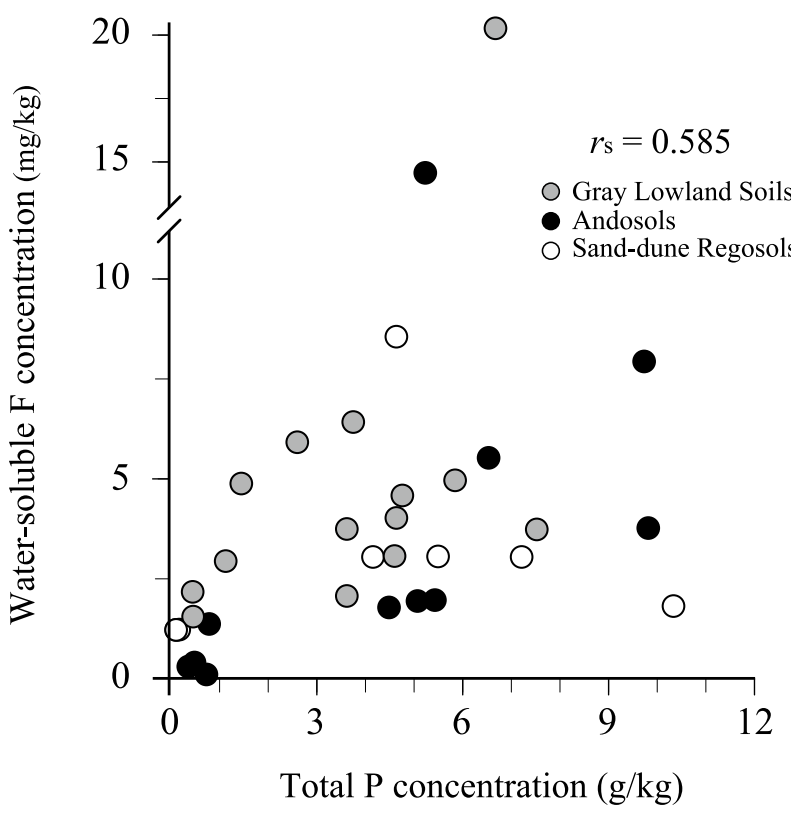

Fig. 3 Relationship between total P concentration and watersoluble $\mathrm{F}$ concentration in non-cultivated soils and greenhouse soils

and the use of phosphate fertilizer, similar to the correlation found for total $\mathrm{F}$ concentration. Furthermore, water-soluble $\mathrm{F}$ concentration also showed a positive correlation with soil pH $\left(r_{\mathrm{s}}=0.558, p=0.001\right)$. This correlation is consistent with the finding of Gilpin and Johnson ${ }^{21}$ that $\mathrm{F}$ solubility in soils in Pennsylvania, USA, increased at $\mathrm{pH}$ values above 6 . This result indicates that water-soluble $\mathrm{F}$ concentration in soil may be partly controlled by soil $\mathrm{pH}$ management. Loganathan et al. ${ }^{22)}$ found that the water-soluble $\mathrm{F}$ concentration was positively related to total $\mathrm{C}$ concentration in New Zealand soils, but such a correlation was not found in this study.

The above results indicate that the water-soluble $\mathrm{F}$ concentration in greenhouse soils in Japan is elevated due to the application of phosphate fertilizer. It is recognized that the water-soluble $\mathrm{F}$ concentration closely reflects plant availability. Although it is known that excessive $\mathrm{F}$ uptake is detrimental to plant growth and yield ${ }^{23}$,24), the critical level of water-soluble $\mathrm{F}$ in soils above which plant growth is affected has not been fully clarified. Thus, we cannot evaluate the effect of the water-soluble $\mathrm{F}$ concentration in the greenhouse soils studied here on crop production. However, no visible injury due to $\mathrm{F}$ toxicity, which is seen as marginal necrosis on foliage, was observed on the cultivated plants (sweet pepper; Capsicum annuum L.) from the greenhouses. It is still necessary to investigate the effect of soil $\mathrm{F}$ accumulation due to the application of phosphate fertilizer on plant growth and yield in the future.

\section{CONCLUSIONS}

The total $\mathrm{F}$ concentration in non-cultivated soils and greenhouse soils ranged from 53 to $248 \mathrm{mg} / \mathrm{kg}$ and from 163 to $471 \mathrm{mg} / \mathrm{kg}$, respectively. All greenhouse soils except three had a higher total F concentration than the neighboring non-cultivated soils, which indicates that the total $\mathrm{F}$ concentration was elevated in almost all greenhouse soils. The amount of $\mathrm{F}$ accumulated in the greenhouse soils was es- 
timated at $17-249 \mathrm{mg}$ per $\mathrm{kg}$ oven-dry soil by subtracting the total $\mathrm{F}$ concentration of the greenhouse soils from that of the neighboring non-cultivated soils. Total F concentration in the soil showed a significant positive correlation with total $\mathrm{P}$ concentration in the soil $\left(r_{\mathrm{s}}\right.$ $=0.683, p<0.001$ ), which suggests that elevation in $\mathrm{F}$ concentration is associated with elevation in $\mathrm{P}$ concentration due to the excessive application of phosphate fertilizer. The water-soluble $\mathrm{F}$ concentrations in non-cultivated and greenhouse soils ranged from 0.15 to 4.89 $\mathrm{mg} / \mathrm{kg}$ and from 1.75 to $20.3 \mathrm{mg} / \mathrm{kg}$, respectively. These concentrations were significantly lower than the total $\mathrm{F}$ concentration, which indicates that most $\mathrm{F}$ in soil is present in insoluble form. All greenhouse soils except four had a higher water-soluble F concentration than the neighboring non-cultivated soils. This shows that not only total F concentration but also water-soluble concentration was correspondingly elevated in greenhouse soils.

\section{ACKNOWLEDGEMENTS}

This work was supported by a Grant-in-Aid for Challenging Exploratory Research from the Japan Society for the Promotion of Science (JSPS KAKENHI Grant Number 25660280).

\section{REFERENCES}

1) Swaine, D.J.; Fluorine, "The trace-element content of fertilizers", pp.102-131, Commonwealth Agricultural Bureaux, England (1962)

2) McLanghlin, M.J., Tiller, K.G., Naidu, R. and Stevens, D.P.: Review: the behaviour and environmental impact of contaminants in fertilizers. Aust. J. Soil Res., 34, 1-54 (1996)

3) Cronin, S.J., Manoharan, V., Hedly, M.J. and Loganathan, P.: Fluoride: a review of its fate, bioavailability and risks of fluorosis in grazed-pasture systems in New Zealand. New Zealand Journal of Agricultural Research, 43, 295-321 (2000).

4) Loganathan, P., Hedley, M.J., Wallace, G.C. and Roberts, A.H.C.: Fluoride accumulation in pasture forages and soils following long-term applications of phosphorus fertilizers. Environmental Pollution, 115, 275-282 (2001)

5) Mishima, S. and Kohyama, K.: The database and the methodologies to estimate recent trend of nitrogen $(\mathrm{N})$ and phosphate $(\mathrm{P})$ flows and residual $\mathrm{N}$ and $\mathrm{P}$ in Japanese national prefectural scales and examples their application. Bull. Natl. Inst. Agro-Environ. Sci, 27, 117-139 (2010) (in Japanese with English abstract)

6) Yoshiike, A.: The status of fertilized phosphate accumulation in agricultural land soil. Jpn. J. Soil Sci. Plant Nutr., 75, 255-261 (1983) (in Japanese)

7) Obara, H. and Nakai, M.: Available phosphate of arable land in Japan. Changes of soil characteristics in Japanese arable land (II). Jpn. J. Soil Sci. Plant Nutr., 75, 59-67 (2004) (in Japanese with English abstract)

8) Yamada, H.,Hattori, T. and Fujita, T: Distribution of fluorine on the cultivated land in Kameoka basin of Kyoto prefecture. The Sci. Rep. Kyoto Prefect. Univ. Agric., 34, 127-134 (1982) (in Japanese with English abstract)

9) Cultivated Soil Classification Committee: Classification of Cultivated Soils in Japan, Third Approximation. Miscellaneous publication of the National Institute of Agro-Environmental Science, No. 17, Tsukuba, Japan (1995) (in Japanese)

10) Soil Environmental Analysis Committee: Soil chemistry, pp.195385, "Soil environmental analysis", Hakuyusya, Tokyo (1997) (in Japanese)

11) Blakemore, L.C. and Searle, P.L: Extractable iron, aluminum and silicon. New Zealand Soil Bur. Sci. Rep., 80, 71-80 (1987)

12) Ministry of the Environment, Environmental Management Bureau: Fluorine, pp.88-98, "Survey method of bottom sediment", Ministry of the Environment (2012) (in Japanese)

13) Hashitani, H., Yoshida, H. and Muto, H.; Simple method for direct photometric determination of traces of fluoride with alizarin complexone, Japan Analyst, 16, 44-46, (1967) (in Japanese with English abstract)

14) Hashitani, H., Yoshida, H. and Adachi, T.; Direct determination of fluoride in water by use of acetylacetone as a demasking agent. Bunseki Kagaku, 28, 680-685 (1979) (in Japanese with English abstract)

15) Okumura, M., Yoshimura, T. Fujinaga, K. and Seika, Y.; Direct spectrophotometric determination of traces of fluoride in rain water. Bunseki Kagaku, 52, 485-488 (2003) (in Japanese with English abstract)

16) Alina, K.P.; Fluorine, pp.385-393, "Trace elements in Soils and Plants" 4th ed., CRC, Florida (2011)

17) Bower, C.A. and Hatcher, J.T.; Adsorption of fluoride by soils and minerals. Soil Science, 103, 151-154 (1967)

18) Pickering, W.F.; The mobility of soluble fluoride in soils. Environmental Pollution, 9, 281-308 (1985)

19) Robinson, W.O. and Edgington, G.: Fluorine in soils. Soil Science, 61, 341-353 (1946)

20) Omueti, J.A.I and Jone, R.L.; Fluoride adsorption by Illinois soils. Journal of Soil Science, 28, 564-572 (1977)

21) Gilpin, L. and Johnson, A.H.; Fluorine in agricultural soils of southern Pennsylvania. Soil Science Society of America Journal, 44, 255-258 (1980)

22) Loganathan, P., Gray, C.W., Hedley, M.J. and Roberts, A.H.C.; Total and soluble fluorine concentrations in relation to properties of soils in New Zealand. European Journal of Soil Science, 57, 411421 (2006)

23) Hara, T. and Sonoda, Y. and Iwai, I.; Growth response of cabbage plants to sodium halides under water culture condition. Soil. Sci. Plant Nutr., 23, 77-84 (1977)

24) Bar-Yosef and Rosenberg, R.; Response of corn and tomato plants to fluorine concentration in solution culture. Agron. J., 80, 173177 (1988) 